\title{
Transforming Growth Factor- $\beta$ Reverses a Posttranscriptional Defect in Elastin Synthesis in a Cutis Laxa Skin Fibroblast Strain
}

\author{
Man-Cong Zhang, * MariaGabriella Giro, * Daniela Quaglino, Jr., ${ }^{\ddagger}$ and Jeffrey M. Davidson*\$ \\ ${ }^{*}$ Department of Pathology, Vanderbilt University School of Medicine, Nashville, Tennessee 37232-2561; ${ }^{\ddagger}$ Istituto di Patologia Generale, \\ Universita di Modena, Modena, Italy; and ${ }^{\S}$ Research Service, Department of Veterans Affairs Medical Center, Nashville, \\ Tennessee 37212
}

\begin{abstract}
Skin fibroblasts from two cases of autosomal recessive cutis laxa (CL), having insignificant elastin production and mRNA levels, were challenged with transforming growth factor beta-1 (TGF-ß1). Elastin production was brought from undetectable values to amounts typical of normal human skin fibroblasts in a dose-dependent fashion. Basic fibroblast growth factor $(100 \mathrm{ng} / \mathrm{ml})$ alone or in combination with TGF- $\beta 1$ reduced elastin production and mRNA expression in CL skin fibroblasts more extensively than in normal cells. In situ hybridization showed that these effects were at the transcript level. One of the $C L$ strains was examined in detail. Transcription rates for elastin were similar in normal and $C L$ and unchanged by TGF- $\beta 1$ or TGF- $\beta 2(10 \mathrm{ng} / \mathrm{ml})$, while in CL elastin mRNA half-life was increased $>10$-fold by TGF- $\beta 2$ and reduced 6-fold after TGF- $\beta 2$ withdrawal, as compared with a control strain. Cycloheximide partially reversed elastin mRNA instability. These data are consistent with a defect in elastin mRNA stability that requires synthesis of labile factors or intact translational machinery, resulting in an extremely low steady state level of mRNA present in this strain of CL. Furthermore, TGF- $\beta$ can relieve elastin mRNA instability in at least one $C L$ strain and elastin production defects in both CL strains. ( J. Clin. Invest. 1995. 95:986-994.) Key words: inherited diseases • growth factors - mRNA stability • posttranscriptional regulation
\end{abstract}

\section{Introduction}

Inherited cutis laxa $(\mathrm{CL})^{1}$ is a rare disease, usually present at birth, with severe skin laxity (1), and it segregates in an autosomal dominant or recessive manner $(1,2)$. In the congenital

Address correspondence to Jeffrey M. Davidson, Ph.D., Department of Pathology C-3321 MCN, Vanderbilt University School of Medicine, Nashville, TN 37232-2561. Phone: 615-327-4751, x5488; FAX: 615327-5393. MariaGabriella Giro's permanent address is Istituto di Istologia ed Embriologia Generale, Facolt̀a di Medicina e Chirurgia, Universita degli Studi di Padova, 35100 Padova, Italy.

Received for publication 10 May 1994 and in revised form 21 September 1994.

1. Abbreviations used in this paper: bFGF, basic fibroblast growth factor; CHX, cycloheximide; CL, cutis laxa; DRB, dichlorobenzimidazole riboside; ELN, gene encoding elastin; GAPDH, glyceraldehyde-3-phosphate dehydrogenase; $\mathrm{mRNA}_{\mathrm{E}}$, elastin messenger RNA; NBCS, newborn calf serum; TE, tropoelastin.

The Journal of Clinical Investigation, Inc

Volume 95, March 1995, 986-994 form, collagen and elastic fibers show ultrastructural abnormalities, with dermal laxity and systemic involvement being more severe in the autosomal recessive form compared with the autosomal dominant form (2-4). Acquired CL, on the other hand, often exists as a complication of an inflammatory episode (5, 6). Morphologic studies of skin biopsies from individuals with congenital CL frequently reveal alterations in the quantity and morphology of elastic fibers, there is often a paucity of elastic fibers or an abnormal organization of the fibers, and the microfibrillar component may appear altered in organization, increased in quantity, or separate from the elastin component (710). Elastin production, evaluated by a specific ELISA, was reported as very low or nearly undetectable in several CL cases (9). Northern blot analysis of elastin mRNA levels in these and several other strains was markedly reduced, showing a clear correlation with elastin production in these strains $(9,11)$.

The elastic fiber provides the elastic properties of many vital tissues of the vertebrate body, including arteries, lung, and dermis. The predominant expression of elastin is developmental and transient (12). Faulty elastin production in heritable or acquired diseases leads to a loss of elastic recoil, and the resulting impaired integrity of elastic fibers plays a major role in the clinical manifestations of a variety of disorders of connective tissue $(13,14)$. Structural alterations in elastic fibers can also be detected in acquired conditions, such as pulmonary emphysema, inflammatory vasculitis, and actinic elastosis. Abnormal elastic fibers are also detected in other heritable, dominant disorders including pseudoxanthoma elasticum (15), supravalvular aortic stenosis (16, 17), Marfan syndrome (18), and Buschke-Ollendorff syndrome (19). The molecular basis of Marfan syndrome is defects in the fibrillin I gene, while supravalvular aortic stenosis appears to arise from large 3 ' deletions/truncations of one elastin allele.

A number of biological signals can regulate elastin production, including steroid hormones (20), phorbol ester (21), and cytokines $(22,23)$. At least some forms of CL might be based on altered signal transduction from extracellular mediators. Of the peptide growth factors, TGF- $\beta$ most strongly affects extracellular matrix formation, and it sharply increases elastin production by cultured smooth muscle cells (24) and skin fibroblasts $(23,25)$. On the other hand, cytokines such as basic fibroblast growth factor (bFGF) and TGF- $\alpha$ can antagonize stimulated elastin production $(23,26)$, while TNF- $\alpha$ can reduce activity of the elastin promoter (27). As do several modulators of elastin production, TGF- $\beta$ increases elastin production, at least in part, by increasing the stability of elastin messenger RNA ( RRNA $_{E}$ ) rather than its transcription (25).

The elastin gene is not known to be absent or structurally altered in CL. In light of the marked deficit in elastin production by many CL strains, we asked whether stimuli such as TGF- $\beta$ and bFGF might differentially affect elastin production in CL. 
The growth factor TGF- $\beta$ was surprisingly able to reverse the decreased elastin phenotype in elastin-deficient strains, and the effect could be largely attributed to changes in transcript stability.

\section{Methods}

Human skin fibroblast cultures. Skin fibroblasts from two CL patients, a 24-mo-old infant (K. T.) and a 6-yr-old child (K. L.), were obtained from upper arm biopsies after appropriate consent (9). Normal human skin fibroblasts GM4390 ( 23 yr old), used as a control strain, were obtained from the National Institute of General Medical Science Human Genetic Mutant Cell Repository (Camden, NJ).

Fibroblasts were maintained in $5 \% \mathrm{CO}_{2}-95 \%$ humidified air at $37^{\circ} \mathrm{C}$ in DME obtained from Gibco Laboratories (Grand Island, NY) containing Hepes buffer ( $25 \mathrm{mM}, \mathrm{pH} 7.6)$, penicillin ( $100 \mathrm{U} / \mathrm{ml})$, streptomycin $(100 \mu \mathrm{g} / \mathrm{ml})$ and $10-20 \%$ heat-inactivated FBS, obtained from Hyclone Labs (Logan, UT). Cells were used at passages 7-11. To reduce assay background in the evaluation of elastin production, cells were fed at confluency with DME, and FBS was switched to $10 \%$ newborn calf serum (NBCS). $0-10 \mu \mathrm{g} / \mathrm{ml}$ recombinant human TGF$\beta 1$ (a gift of Genentech, Inc., South San Francisco, CA) or TGF- $\beta 2$ (a gift of Celtrix, Inc., Santa Clara, CA) was added to just-confluent cultures alone or in the presence of $100 \mathrm{ng} / \mathrm{ml}$ bFGF (a gift of Synergen, Inc., Boulder, $\mathrm{CO}$ ). Media were harvested after $48 \mathrm{~h}$, the cell layers were washed with cold PBS, and both samples were stored at $-20^{\circ} \mathrm{C}$ until assays were performed.

Cells for in situ hybridization were subcultivated in triplicate in 8well culture chamber slides $\left(1 \mathrm{~cm}^{2} /\right.$ well $)$ supplied by Lab-Tek, Nunc, Inc. (Naperville, IL), fixed in $4 \%$ paraformaldehyde obtained from Fluka Chemical Corp. (Ronkonkoma, NY) in PBS containing $5 \mathrm{mM}$ $\mathrm{MgCl}_{2}$, at $4^{\circ} \mathrm{C}$ for $30 \mathrm{~min}$ (28), washed in PBS, dehydrated in graded ethanol, and stored in $80 \%$ ethanol at $4^{\circ} \mathrm{C}$ for a few days until the hybridization procedure was performed.

Enzyme-linked immunoassay. A standard ELISA was used to evaluate elastin production as previously described (29). Rabbit antiserum to pig a-elastin was used at a 1:4,000 dilution, plates were coated with $40 \mathrm{ng}$ of human a-elastin, and the test was made specific for quantitating soluble tropoelastin (TE) by using a range of 22-0.17 ng/well of pig $\mathrm{TE}$ as a competing antigen to construct a standard curve. Data were analyzed by MacReader software obtained from Bio-Rad (Melville, NY). Elastin production was expressed as molecular equivalents/ cell $\cdot \mathrm{h}$.

DNA assay. DNA content of confluent cell layers was evaluated by a fluorometric procedure using Hoescht 33258 supplied by Boehringer Mannheim Biochemicals (Indianapolis, IN), as previously described $(30,31)$.

In situ hybridization. Two cDNA probes were used: (1) cHE-4, 1.0$\mathrm{kb}$ human elastin cDNA fragment cleaved with BamHI and HindIII from a larger insert in the EcoRI site of a Bluescript plasmid supplied by Stratagene (La Jolla, CA), which corresponds to exons 18-36 of human elastin gene (32); (2) HF1131, a 1.9-kb collagen type I cDNA insert in the EcoRI site of pBR322 corresponding to the COOH-terminal portion of the pro $\alpha 2$ chain of human type I procollagen (33). We followed a hybridization procedure previously described (34), with some modifications. In brief, slides were pretreated with $0.25 \%$ acetic anhydride in $0.1 \mathrm{M}$ triethanolamine, $\mathrm{pH} 8.0\left(10 \mathrm{~min}, 20^{\circ} \mathrm{C}\right)$, denatured with $50 \%$ formamide (Fisher Scientific, Pittsburgh, PA) in $2 \times \operatorname{SSC}(8$ $\min , 60^{\circ} \mathrm{C}$ ), and dehydrated. $40 \mu \mathrm{l}$ of the hybridization solution containing $10,000 \mathrm{dpm} / \mu \mathrm{l}$ of the radiolabeled probe was added to the slides which were then covered with siliconized, baked coverslips and sealed. The hybridization was carried on for FF7E $15 \mathrm{~h}$ at $40^{\circ} \mathrm{C}$ followed by washes in $2 \times$ SSC plus $30 \%$ formamide and then stringency washes in decreasing concentrations of SSC. Dehydrated slides were dipped in the NTB-2 Kodak autoradiographic emulsion and stored for 8-10 d at $4^{\circ} \mathrm{C}$. Developed slides were stained with hematoxylin and eosin and observed under an optical microscope in bright and dark field.
Nuclear run-on transcription. Confluent $\mathrm{CL}$ and normal fibroblasts were treated with $10 \mathrm{ng} / \mathrm{ml}$ TGF- $\beta 2$ for $48 \mathrm{~h} .1-2 \times 10^{7}$ nuclei from each cell strain were lysed in $1 \mathrm{ml}$ Nonidet P-40 (NP-40) buffer ( 10 $\mathrm{mM}$ Tris- $\mathrm{HCl}, \mathrm{pH} 7.4,10 \mathrm{mM} \mathrm{NaCl}, 3 \mathrm{mM} \mathrm{MgCl} 2,0.5 \% \mathrm{NP}-40$ ) for $5 \mathrm{~min}$ on ice and centrifuged at $500 \mathrm{~g}$ for $5 \mathrm{~min}$. NP-40 was from Sigma Chemical Co. (St. Louis, MO). Nuclei were washed with $2 \mathrm{ml}$ of NP40 buffer, and nuclei were resuspended in $100 \mu 150 \mathrm{mM}$ Tris- $\mathrm{HCl}, \mathrm{pH}$ 8.3, $40 \%$ glycerol, $5 \mathrm{mM} \mathrm{MgCl}, 0.1 \mathrm{mM}$ EDTA for storage in liquid nitrogen. The nuclei were thawed for the run-on transcription assay, mixed with $100 \mu \mathrm{l}$ of reaction buffer ( $10 \mathrm{mM}$ Tris- $\mathrm{HCl}, \mathrm{pH} 8.0,5 \mathrm{mM}$ $\mathrm{MgCl}_{2}, 300 \mathrm{mM} \mathrm{KCl}, 0.5 \mathrm{mM}$ each of ATP, CTP, and GTP) and 100 $\mu \mathrm{Ci}$ of $\left[\alpha-{ }^{32} \mathrm{P}\right] \mathrm{UTP}$ from DuPont/New England Nuclear (Boston, MA) $(3,000 \mathrm{Ci} / \mathrm{mmol})$, and reacted at $30^{\circ} \mathrm{C}$ for $30 \mathrm{~min}$. Plasmid DNA ( 15 $\mathrm{mg}$ ) in water was applied to a Zeta-Probe membrane supplied by BioRad (Richmond, CA), using a Minifold II Slot-Blot system obtained from Schleicher \& Schuell, Inc. (Keene, NH). The membrane was baked at $80^{\circ} \mathrm{C}$ for $2 \mathrm{~h}$, then denatured in $0.5 \mathrm{M} \mathrm{NaOH}$, for $5 \mathrm{~min}$ at room temperature, neutralized in $1.5 \mathrm{M} \mathrm{NaCl}, 0.5 \mathrm{M}$ Tris, $\mathrm{pH} 7.5$, for $5 \mathrm{~min}$ at room temperatures, and washed in $2 \times$ SSC. The individual slots contained cDNA inserts for human elastin (32), human COL1A2 (33), mouse COLAAI (35), human fibronectin (36), and mouse glyceraldehyde-3-phosphate dehydrogenase (GAPDH; a gift of Dr. Peter Curtis, Wistar Institute, Philadelphia, PA), mouse TNF- $\alpha$ (37), and human collagenase (38). The RNA molecules thus synthesized were hybridized in $7 \% \mathrm{SDS}, 1 \mathrm{mM}$ EDTA, and $250 \mathrm{mM} \mathrm{Na}_{2} \mathrm{PO}_{4}$ at $65^{\circ} \mathrm{C}$ for $48 \mathrm{~h}$. In an earlier experiment, cells were treated with $10 \mathrm{ng} / \mathrm{ml}$ TGF- $\beta 1$, and the RNA molecules were hybridized to $10 \mu \mathrm{g}$ plasmid DNA containing all the cDNA inserts just described except for TNF- $\alpha$ and human collagenase. The filters were washed twice for 30 min each in $1 \mathrm{mM}$ EDTA, $40 \mathrm{mM} \mathrm{Na} \mathrm{HPO}_{4}, \mathrm{pH} 7.2,5 \%$ SDS at $65^{\circ} \mathrm{C}$ and incubated at $37^{\circ} \mathrm{C}$ in $2 \times$ SSC with $10 \mu \mathrm{g} / \mathrm{ml}$ RNase A (Sigma Chemical Co.) for $30 \mathrm{~min}$. The filters were then washed twice in $1 \mathrm{mM}$ EDTA, $40 \mathrm{mM} \mathrm{Na}{ }_{2} \mathrm{HPO}_{4}$, $1 \% \mathrm{SDS}$ at $65^{\circ} \mathrm{C}$ for $30 \mathrm{~min}$. Autoradiography to detect hybridizable transcripts was for 5-7d with an intensifying screen. The optical densities of autoradiographic signals for each transcript were normalized to that for $G A P D H$, and the transcription values were calculated as the ratio of each transcript signal relative to the GAPDH signal.

$m R N A$ half-life. Confluent $\mathrm{CL}$ strain $\mathrm{K}$. T. cells were pretreated with $10 \mathrm{ng} / \mathrm{ml}$ TGF- $\beta 2$ in DME, $10 \%$ FBS for $48 \mathrm{~h}$ and then washed three times with PBS. Fresh media with or without $10 \mathrm{ng} / \mathrm{ml}$ TGF- $\beta 2$, containing $60 \mu \mathrm{M}$ 5,6-dichlorobenzimidazole riboside (DRB; reference 25), supplied by Sigma Chemical Co., from a stock solution of $20 \mathrm{mM}$ in isopropanol, was added to cultures $(t=0)$. Control fibroblasts, GM4390, were treated with the cytokine at $t=0$ together with DRB. 6,12 , and $24 \mathrm{~h}$ after addition of DRB, cells were washed twice in PBS buffer and lysed in $2 \mathrm{ml} 4 \mathrm{M}$ guanidine isothiocyanate containing 0.1 $\mathrm{mM} \beta$-mercaptoethanol. DNA was sheared by passage three times through a 22-gauge needle, and RNA was isolated by extraction in acid phenol/chloroform (39). For Northern hybridization, 15-20 $\mu \mathrm{g}$ of total RNA was denatured in $50 \%$ formamide, $1 \mathrm{M}$ formaldehyde at $68^{\circ} \mathrm{C}$ for $10 \mathrm{~min}$ and separated by electrophoresis through a $1 \%$ agarose gel containing $1 \mathrm{M}$ formaldehyde. RNA was transferred by capillary action to nylon membranes supplied by Micron Separations Inc. (Westboro, MA), crosslinked by ultraviolet irradiation for $1 \mathrm{~min}$, and baked for 30 min at $80^{\circ} \mathrm{C}$. Membranes were hybridized as described in the previous section, washed, and exposed to $\mathrm{x}$-ray film. The elastin probe, EUTR1 , was derived from a genomic clone obtained by screening a phage $\lambda$ library (provided by Dr. M. Leppert, University of Utah School of Medicine, Salt Lake City, UT) with a sheep genomic DNA probe (pSS1; reference 40). A 1.65-kb HindIII-PstI fragment beginning in the $\mathrm{COOH}-$ terminal coding region of elastin and extending beyond the transcription termination site was subcloned into pGEM4z obtained from Promega Corp. (Madison, WI). The 1.9-kb human COL1A2 cDNA clone (HF1131; reference 33), and a cyclophilin probe, 1B15 (40), prepared by random priming according to instructions from the manufacturer (Stratagene, La Jolla, CA), were also used in hybridization studies. Autoradiograms were evaluated by densitometric scanning. Specific 


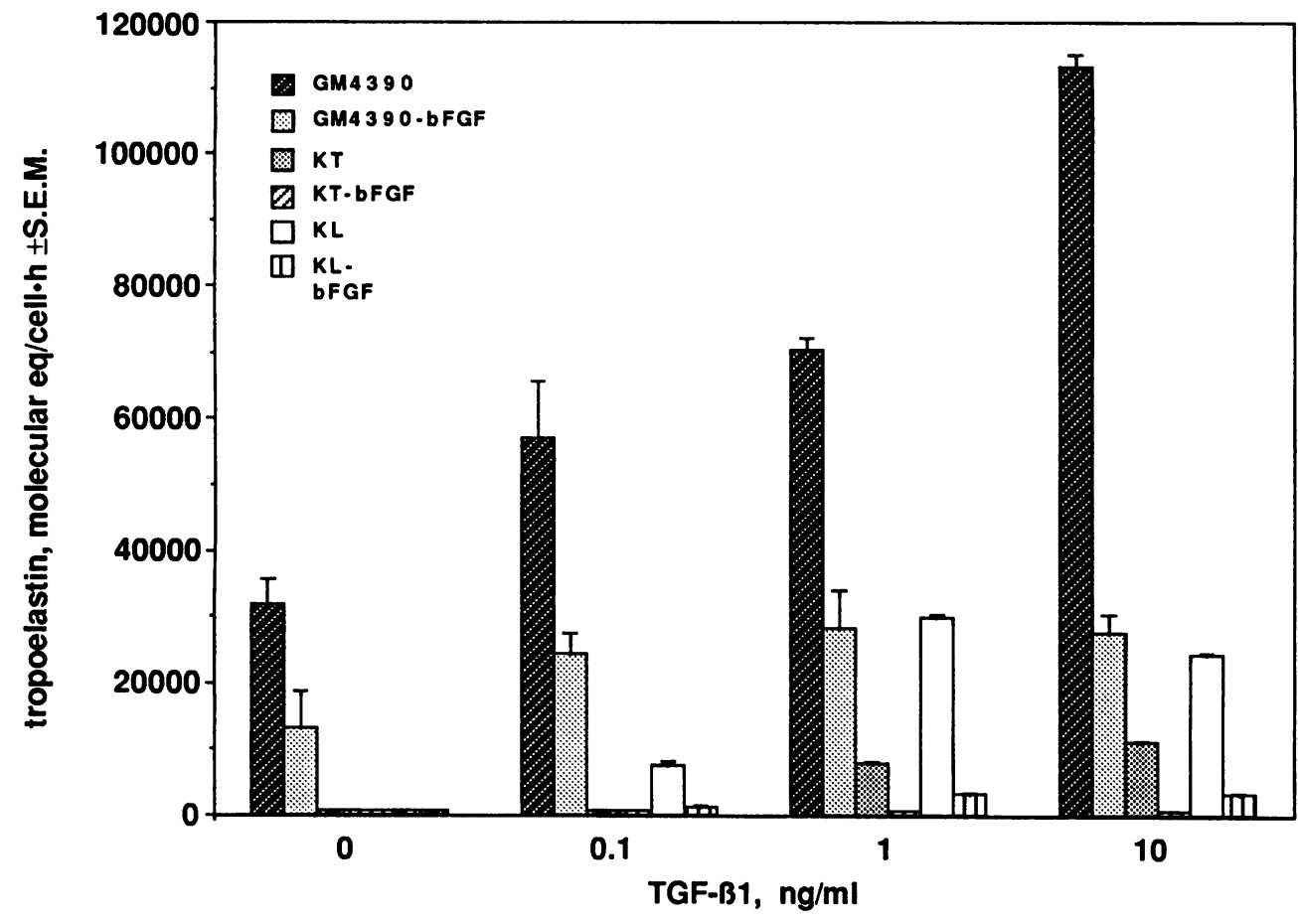

Figure 1. Effect of growth factors on TE production in normal (GM4390) and CL (K. T.; K. L.) fibroblast strains. Fibroblasts in 8 well culture-chamber slides were fed at confluency with $300 \mu \mathrm{l}$ DME, $10 \%$ NBCS, and increasing amounts $(0,0.1,1.0$, and $10.0 \mathrm{ng} /$ $\mathrm{ml}$ ) of TGF- $\beta 1$ in the presence or absence of $100 \mathrm{ng} / \mathrm{ml}$ bFGF. Media were harvested after $48 \mathrm{~h}$, and elastin production was evaluated by an ELISA. Data are expressed as molecular equivalents produced per cell per hour \pm SEM.
mRNA expression was normalized to cyclophilin or the staining intensity of the $28 \mathrm{~S}$ ribosome band.

Calculation of decay kinetics was based on a logarithmic transformation of initial decay rates $(0-12 \mathrm{~h})$ for each treatment group, and the slopes of the regression lines were used to estimate $t_{1 / 2}$. Significance of differences between control and $\mathrm{K}$. T. $\mathrm{mRNA}_{\mathrm{E}}$ stability could be tested by pooling the data and using the slopes of the decay curves and the standard error of the regression estimate to calculate a value of $t$.

Elastin $m R N A$ decay kinetics after withdrawal of TGF- $\beta$. Confluent cultures of K. T. and GM4390 fibroblast strains were treated for $2 \mathrm{~d}$ with $10 \mathrm{ng} / \mathrm{ml}$ of TGF- $\beta 2$ in DME containing $10 \%$ FBS. Cells were washed $5 \times$ with PBS, and refed with fresh DME, 10\% FBS. $2 \mathrm{~d}$ after withdrawal of TGF- $\beta 2,20 \mu \mathrm{g} / \mathrm{ml}$ cycloheximide (CHX) (Sigma Chemical Co.) was added to one set of cultures for $2 \mathrm{~d}$. RNA was isolated at $0,1,2,3$, and $4 \mathrm{~d}$ after TGF- $\beta 2$ withdrawal. In a second experiment, $\mathrm{CHX}$ was added to the $\mathrm{K}$. T. fibroblasts at the time of withdrawal of TGF- $\beta$, and RNA was isolated at 0,1 , and 2 d. $15 \mu \mathrm{g}$ of total RNA was separated on a $1 \%$ agarose gel containing $1 \mathrm{M}$ formaldehyde and transferred to a nylon membrane obtained from MagnaGraph (Westboro, MA). The 1.65-kb human elastin EUTR-1 and 0.6-kb cyclophilin (40) cDNA probes were used for hybridization.

The apparent $t_{1 / 2}$ for decay of $\mathrm{mRNA}_{\mathrm{E}}$ was calculated from a logarithmic transformation of the signal data versus time. Slopes and standard errors of the regression estimates were used to calculate a value of $t$.

\section{Results}

Upregulation of elastin in $C L$ strains by $T G F-\beta$. Cultured fibroblasts were grown to confluency and then incubated with DME, $10 \%$ NBCS containing $0-10 \mathrm{ng} / \mathrm{ml}$ of TGF- $\beta 1$ with or without $100 \mathrm{ng} / \mathrm{ml}$ of bFGF. As previously observed, elastin production in the $\mathrm{CL}$ fibroblast strains under standard culture conditions was negligible or below the level of detection of the ELISA assay (Fig. 1). When TGF- $\beta$ was added to K. T. and $K$. L. cultures, elastin accumulation in these cell strains was strongly stimulated, bringing production from undetectable values to one third of the level of normal production in strain $\mathrm{K}$. T. and to values similar to those of normal skin fibroblasts in strain K. L.

Under standard culture conditions, the addition of $100 \mathrm{ng} /$ $\mathrm{ml}$ bFGF to the control strain reduced elastin production by about twofold. In the presence of the same concentration of bFGF, the TGF- $\beta$-dependent stimulation of elastin production was strongly inhibited in CL strains K. L. and K. T. The degree of reduction in the two CL strains was much greater than that of the normal strain, elastin production being reduced to undetectable values for strain $\mathrm{K}$. T., and approximately eightfold in strain K. L. (Fig. 1).

Elastin mRNA ( $\mathrm{mRNA}_{\mathrm{E}}$ ) levels and the homogeneity of the cellular response to cytokines were assessed by in situ hybridization. In the cells from a normal donor (Fig. 2, NORMAL), substantial expression of mRNA $_{\mathrm{E}}$ could be seen even in the absence of TGF- $\beta 1$ in the medium. By contrast, cells from the patient K. T. (Fig. 2, CUTIS LAXA) presented a very low number of silver grains per cell. The administration of increasing concentrations of TGF- $\beta 1(0-10 \mathrm{ng} / \mathrm{ml})$ brought about a progressive, dose-dependent increase in $\mathrm{mRNA}_{\mathrm{E}}$ accumulation in both cell strains. Reduced transcript abundance was brought about by the addition of bFGF $(100 \mathrm{ng} / \mathrm{ml})$ to these strains.

In Fig. 3 normal and CL cells were hybridized with a probe for COL1A2 mRNA. There were no remarkable differences in transcript abundance in normal and CL strains (also see Fig. 5 ), TGF- $\beta$ stimulated collagen type I mRNA accumulation in both strains, and this stimulation was partially reversed by the addition of bFGF ( $100 \mathrm{ng} / \mathrm{ml})$.

Reduced elastin mRNA in CL strain K. T. is not attributable to transcription. To determine further the mechanism for reduced steady-state levels of $\mathrm{mRNA}_{\mathrm{E}}$ in strain $\mathrm{K}$. T., nuclear run-on transcription studies were performed (Fig. 4). Stocks of strain K. L. were too depleted to perform parallel studies. Despite the remarkably reduced $\mathrm{mRNA}_{\mathrm{E}}$ level, $\mathrm{K}$. T. strain appeared to have an elastin transcription rate very similar to a control strain. Represented in Table $I$ is the ratio of elastin 

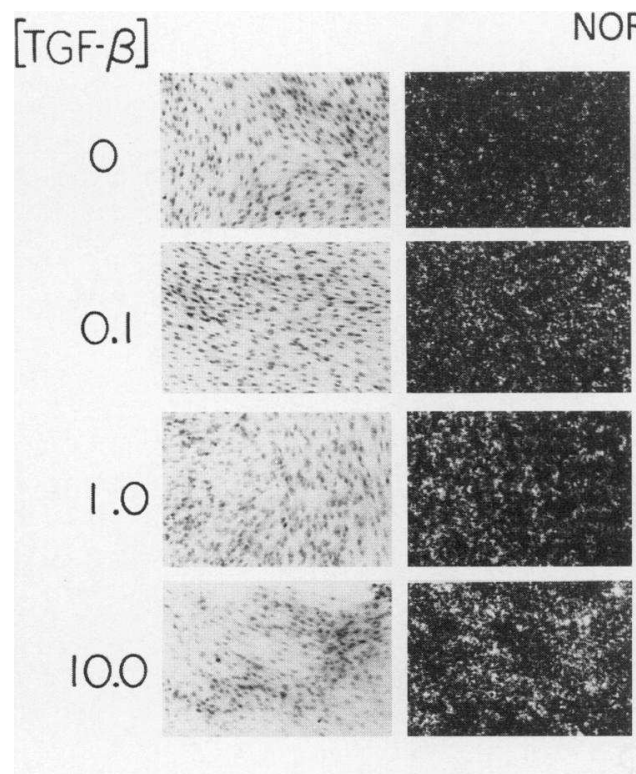

\section{NORMAL}
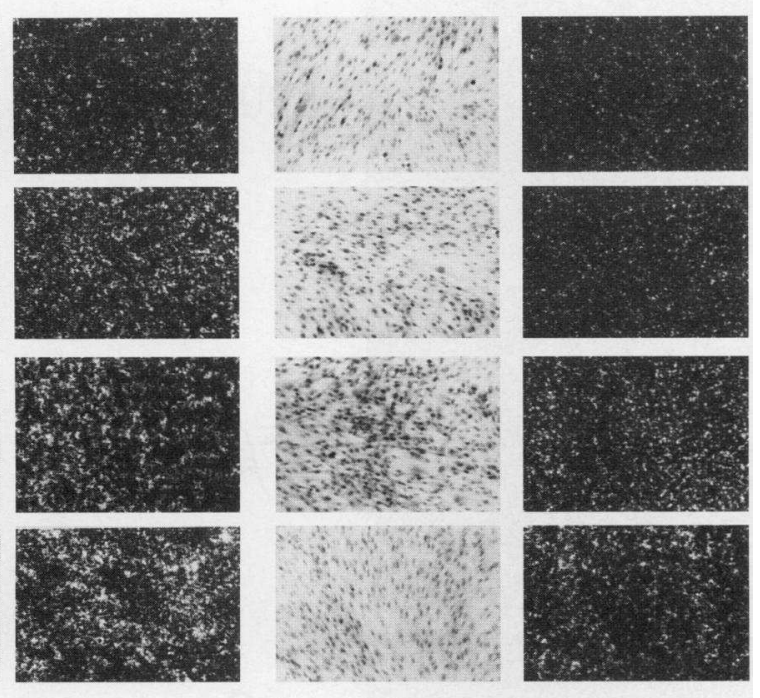

\section{CUTIS LAXA}

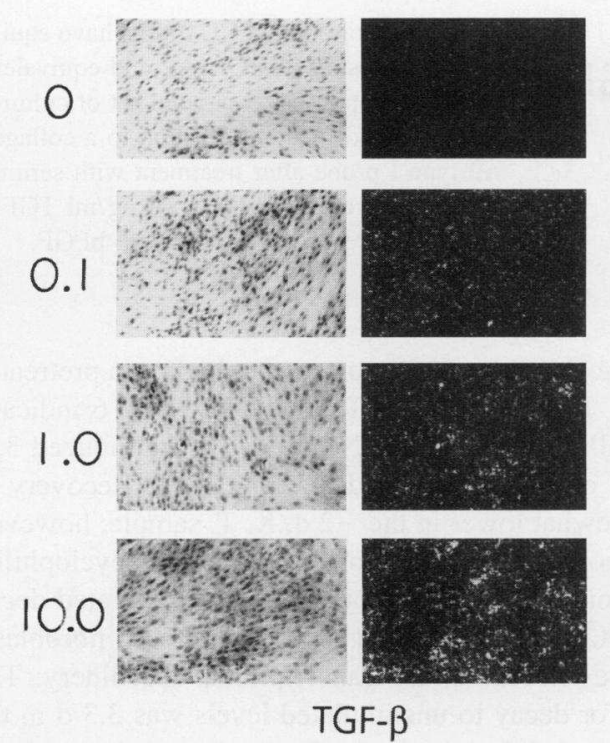

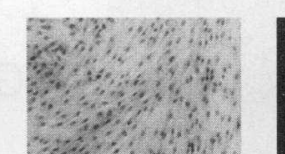
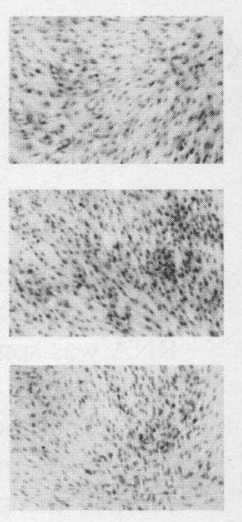

TGF- $\beta+$ bFGF (100)
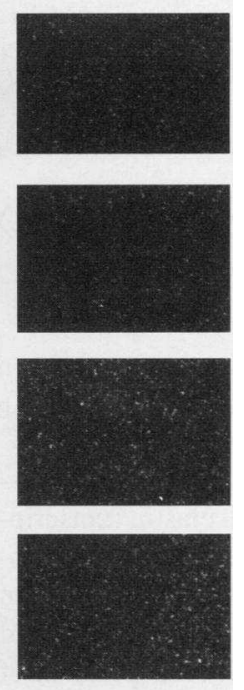

Figure 2. In situ hybridization of normal (GM4390) and CL (K. T.) strains. Confluent fibroblast cultures, treated as described in Fig. 1 , were fixed with paraformaldehyde and processed for in situ hybridization with cHE-4, a human elastin cDNA probe which corresponds to exons 18-36 of human elastin gene. The upper panel shows response of normal cells while the lower panel shows the response of CL strain K. T. In the two left columns of both panels the appearance and $m R N A_{E}$ abundance in cells treated with increasing quantities of TGF- $\beta$ alone are indicated. In the right columns, in addition to TGF- $\beta 1,100 \mathrm{ng} / \mathrm{ml}$ of bFGF was added to the culture medium. Bright-field (left) and dark-field (right) images from both cell strains are shown. and other matrix gene transcripts to the hybridization signal of $G A P D H$ in $\mathrm{K}$. T. and normal fibroblasts as determined by scanning densitometry of autoradiograms. Apparent elastin transcription rates for both $\mathrm{K}$. T. CL fibroblasts and the control strain were unaffected by $48 \mathrm{~h}$ of exposure of cultures to 10 $\mathrm{ng} / \mathrm{ml}$ TGF- $\beta 2$. While the values for elastin transcription rate did not change in the presence of TGF- $\beta 2$ (experiment A), there were significant increases in the transcription rates of COL1A2 and FN.

The rescue of TE production by TGF- $\beta$ is associated with transient stabilization of $m R N A_{E}$ in $K . T$. strain. Since we observed no significant difference in elastin transcription between a normal and a CL cell strain, these data suggested a defect in elastin expression at a posttranscriptional level. To assess if this mechanism involved degradation of $\mathrm{mRNA}_{E}$, we studied the decay kinetics of this transcript. Since mRNA $_{E}$ was only accumulated in K. T. cells after TGF- $\beta$ stimulation, the decay of elastin mRNA K. T. cells was followed after pretreatment with
$10 \mathrm{ng} / \mathrm{ml}$ TGF- $\beta$. Subsequently, new transcription was shut off by adding DRB, and mRNA decay was followed, with and without withdrawal of TGF- $\beta 2$, by Northern blot hybridization. Under these conditions, stability of $\mathrm{mRNA}_{E}$ in vascular smooth muscle cells is increased about twofold (Zoia, O., and J. M. Davidson, unpublished observations). Elastin mRNA from K. T. fibroblasts was markedly less stable, as shown in Fig. 5. In fact, within $6 \mathrm{~h}$ after withdrawal of TGF- $\beta 2$ in the presence of DRB, the mRNA was barely detectable by Northern blotting. Estimated $t_{1 / 2}$ of mRNA $_{E}$ in the K. T. strain was $<15 \mathrm{~min}$. On the other hand, continuous presence of TGF- $\beta 2$ in K. T. cells transiently stabilized $\mathrm{mRNA}_{\mathrm{E}}$, increasing the apparent $t_{1 / 2}$ to $2.5 \mathrm{~h}$ (18×; Fig. 5). In control cells, the $\mathrm{mRNA}_{\mathrm{E}}$ was much more stable, with a $t_{1 / 2}$ of FF7E $8 \mathrm{~h}$ in this system. This betweenstrain difference in half-lives in the presence of TGF- $\beta$ corresponded well to differences in elastin accumulation (Fig. 1). Addition of TGF- $\beta$ at the time of transcription inhibition appeared to have only a transient, mild effect on $\mathrm{mRNA}_{E}$ stability 

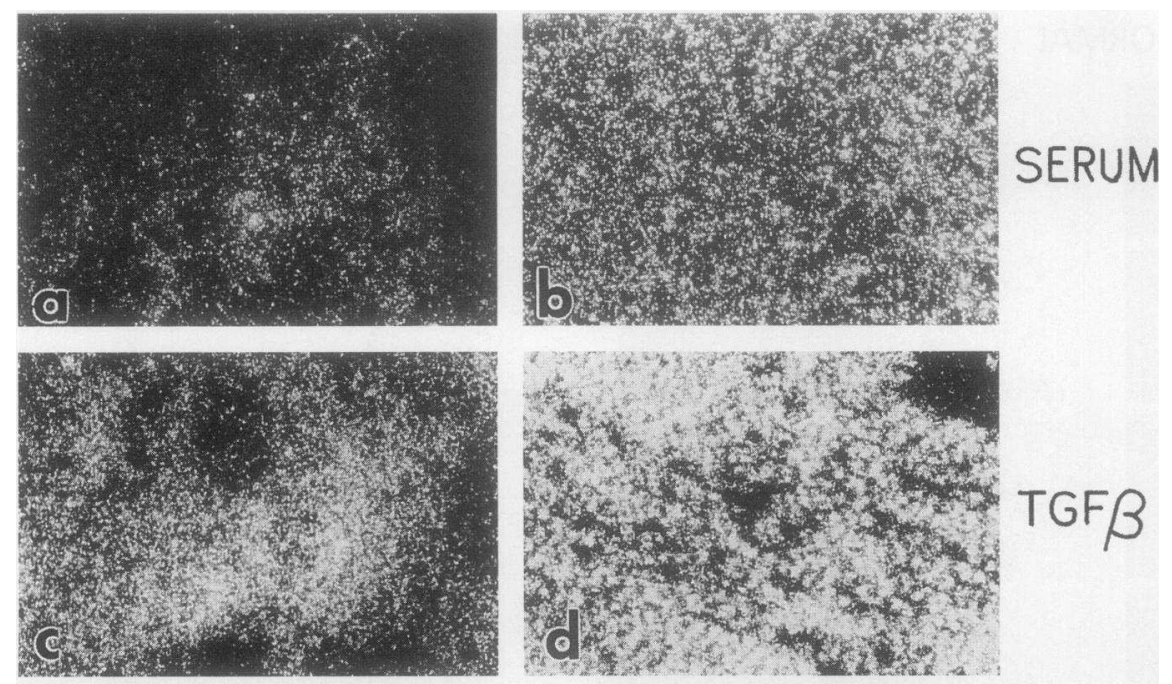

\section{TGF $\beta$}
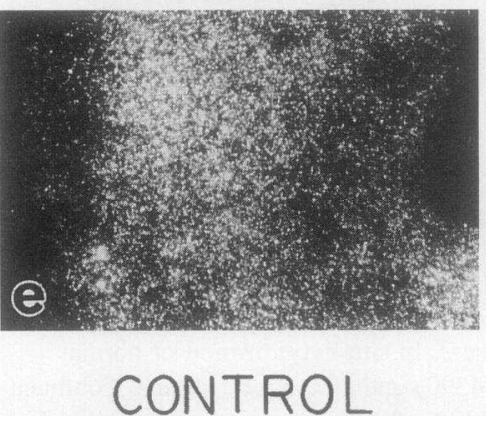

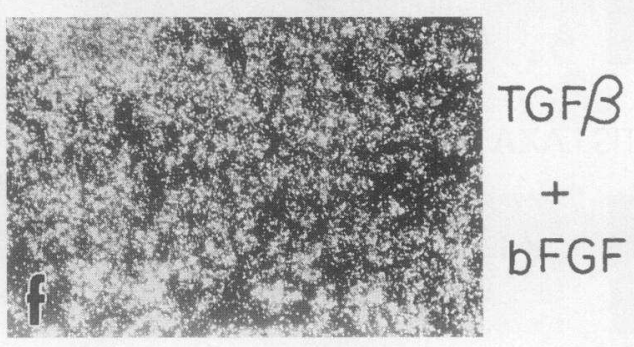

CUTIS LAXA
Figure 3. Normal and CL strains have equivalent expression of COL1A2 and equivalent cytokine responses. A parallel set of cultures was prepared for hybridization to a collagen $\alpha 2$ type I probe after treatment with serum only, $10 \mathrm{ng} / \mathrm{ml}$ TGF- $\beta 1$ or $10 \mathrm{ng} / \mathrm{ml}$ TGF$\beta 1$ in the presence of $100 \mathrm{ng} / \mathrm{ml} \mathrm{bFGF}$. in control cells. Irrespective of TGF- $\beta$ treatment there was a highly significant difference between control and $\mathrm{K}$. T. $\mathrm{mRNA}_{\mathrm{E}}$ stability (greater than sixfold; $P<0.02, t$ test).

Withdrawal of TGF- $\beta$ stimulation causes a more rapid decay of $m R N A_{E}$ in $C L$ strain $K$. T. Since apparent elastin transcriptional rates were identical in normal and CL strains, while apparent mRNA half-lives were markedly different, changes in mRNA levels upon TGF- $\beta$ introduction or withdrawal should be a means of detecting altered mRNA stability independent of transcriptional blockage. To test this assumption, we followed elastin mRNA levels after induction and withdrawal of TGF- $\beta 2$ in both normal and $\mathrm{K}$. T. fibroblasts that had been pretreated with $10 \mathrm{ng} / \mathrm{ml}$ TGF- $\beta 2$ for $2 \mathrm{~d}$. The results in Fig. 6 indicate, as previously illustrated, that $\mathrm{mRNA}_{\mathrm{E}}$ levels were induced 3.2fold in control cells and 16.5 -fold in strain $\mathrm{K}$. T. Recovery of RNA was somewhat lower in the $-2 \mathrm{~d}, \mathrm{~K}$. T. sample; however, all data were normalized to the constitutive probe, cyclophilin. This experiment confirmed that there was an accelerated decay of mRNA $_{E}$ in CL cells compared with normal skin fibroblasts even in the presence of intact transcriptional machinery. The estimated $t_{1 / 2}$ for decay to unstimulated levels was $3.3 \mathrm{~d}$ in the control strain and $0.5 \mathrm{~d}$ in strain $\mathrm{K}$. T. Comparison of the

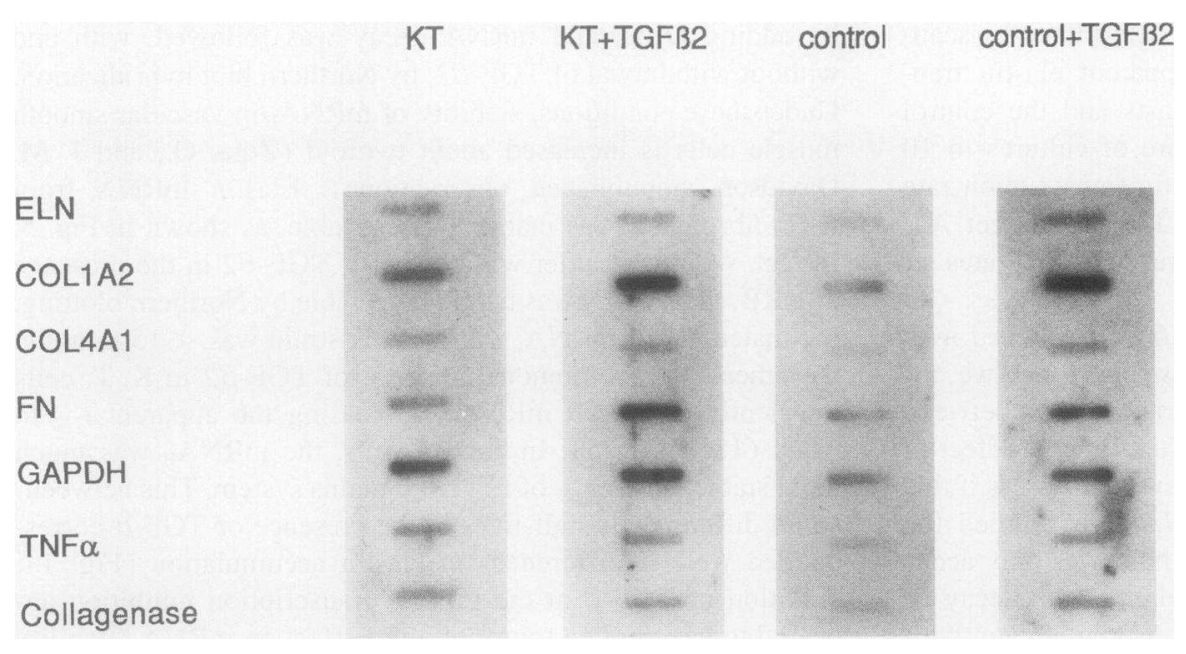

Figure 4. Nuclear run-on transcription in fibroblasts from normal and CL skin. CL strain K. T. and normal fibroblast strain GM4390 were grown to confluency in DME, $10 \%$ FBS. Duplicate cultures were treated with 10 $\mathrm{ng} / \mathrm{ml}$ TGF- $\beta 2$ for $48 \mathrm{~h}$. $1-2 \times 10^{7}$ nuclei from each cell culture were isolated, lysed, and used for a run-on transcription assay as described in Methods. Radiolabeled RNA probes were hybridized to $15 \mathrm{mg}$ of immobilized plasmid DNA containing cDNA inserts encoding human elastin HDE1 (row 1), human COLIA2 (row 2), mouse COLAA1 (row 3 ), human fibronectin ( $F N$, row 4$)$, mouse GAPDH (row 5), mouse TNF- $\alpha$ (row 6 ), and human collagenase (row 7). The optical densities of autoradiographic signals for each transcript normalized to that for $G A P D H$ are presented in Table I. 
Table I. Relative Transcription Rates of Elastin and Other Matrix Genes in CL Fibroblasts

\begin{tabular}{|c|c|c|c|c|}
\hline \multirow[b]{2}{*}{ Cell strains } & \multicolumn{2}{|c|}{ K.T. } & \multicolumn{2}{|c|}{ Control } \\
\hline & - & + & - & + \\
\hline \multicolumn{5}{|c|}{$\begin{array}{l}\text { Experiment } A^{*} \text { TGF- } \beta 2 \\
(10 \mathrm{ng} / \mathrm{ml})\end{array}$} \\
\hline ELN & 0.35 & 0.36 & 0.3 & 0.4 \\
\hline COL1A2 & 0.75 & 1.32 & 0.91 & 1.7 \\
\hline COL4A1 & 0.27 & 0.28 & 0.28 & 0.3 \\
\hline FN & 0.56 & 1.0 & 0.7 & 1.0 \\
\hline TNF- $\alpha$ & 0.47 & 0.41 & 0.4 & 0.5 \\
\hline Collagenase & 0.37 & 0.39 & 0.35 & 0.47 \\
\hline & - & + & & + \\
\hline \multicolumn{5}{|c|}{$\begin{array}{l}\text { Experiment } B^{\ddagger} \text { TGF- } \beta 1 \\
\quad(10 \mathrm{ng} / \mathrm{ml})\end{array}$} \\
\hline ELN & 0.71 & 0.70 & & 1.05 \\
\hline COL1A2 & 1.06 & 1.07 & & 1.38 \\
\hline COL4A1 & 0.47 & 0.42 & & 0.47 \\
\hline FN & 2.12 & 2.00 & & 2.13 \\
\hline
\end{tabular}

Numbers represent the ratio of elastin and other matrix gene transcripts to the hybridization signal of GAPDH in CL fibroblasts and control fibroblasts as determined by scanning densitometry of the autoradiogram from the run-on transcription experiment present in Fig. 4. * In experiment A cells were stimulated with $10 \mathrm{ng} / \mathrm{ml} \mathrm{TGF-} \beta 2$, and $15 \mu \mathrm{g}$ of DNA was used in hybridization. ${ }^{\ddagger}$ In experiment $B$ cells were stimulated with $10 \mathrm{ng} / \mathrm{ml}$ TGF- $\beta 1$, and $10 \mu \mathrm{g}$ of DNA was used in hybridization.

regression lines showed highly significant differences in these rates $(P<0.01, t$ test $)$. In the set of cultures in Fig. $6 B$ protein synthesis was blocked with $\mathrm{CHX} 2 \mathrm{~d}$ after TGF- $\beta$ withdrawal. This treatment slowed the $\mathrm{mRNA}_{\mathrm{E}}$ decay in both normal and $\mathrm{CL}$ fibroblast strains, although $\mathrm{mRNA}_{\mathrm{E}}$ decay in the $\mathrm{CL}$ strain was already nearly complete. At day 4, mRNA $_{E}$ was $140 \%$ higher in controls and $10 \%$ higher in $\mathrm{K}$. T. cells treated with $\mathrm{CHX}$.

To confirm the decay and $\mathrm{CHX}$ effects, $\mathrm{CHX}$ was added to another set of cultures at the time of withdrawal of TGF- $\beta 2$, and this earlier blockage of protein synthesis markedly reduced $\mathrm{mRNA}_{\mathrm{E}}$ decay. By scanning densitometry of the autoradiogram, we found that the presence of $\mathrm{CHX}$ in $\mathrm{K}$. T. cultures increased mRNA $_{E}$ levels by $250 \%$ at day 1 and $75 \%$ at day 2 relative to cultures grown in the absence of the drug (Fig. $6 \mathrm{~B}$, inset).

\section{Discussion}

In a subset of CL patients with severe, congenital onset of symptoms, affected individuals present with wrinkled and sagging skin, giving the appearance of premature aging, as well as having internal organ involvement. In the most severely affected individuals, elastic fibers are either absent or severely deranged in the skin as well as other elastic structures. Severely affected individuals often succumb to pulmonary failure in the first few years of life. In a previous study by Sephel et al. (9) it was shown that, although heterogeneity exists among individuals in the capacity of their skin fibroblasts to produce elastin, reduced elastin production is a distinctive feature of at least some CL

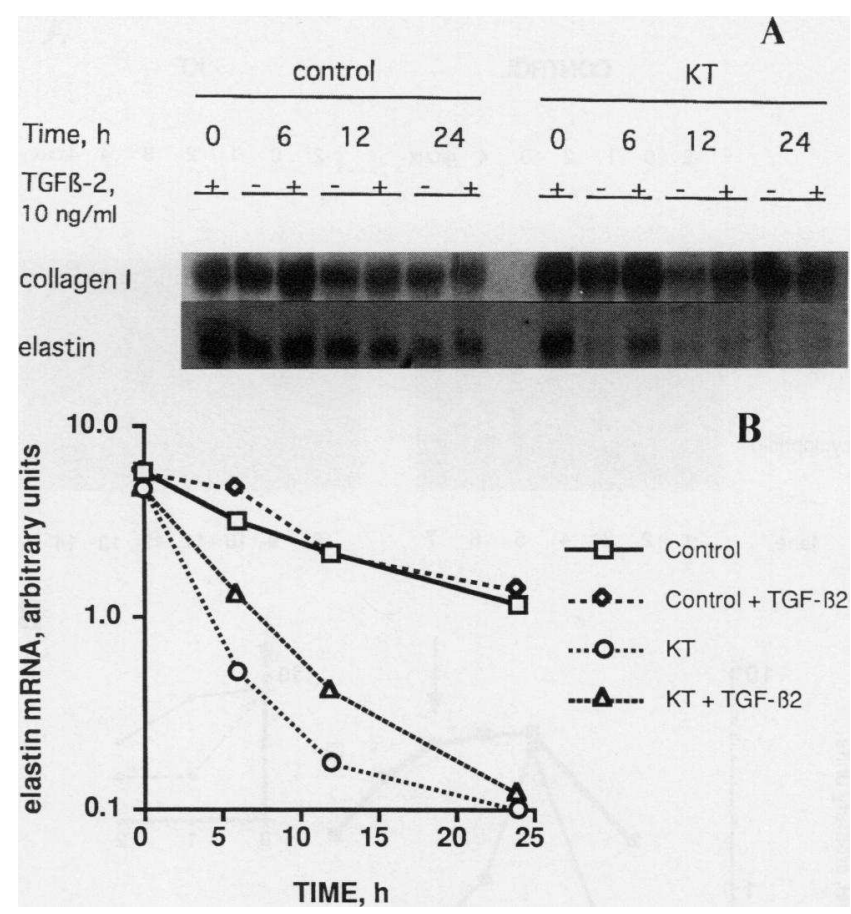

Figure 5. Stability of COL1A2 and ELN transcripts in CL and normal skin fibroblasts. $A$ shows an autoradiogram of a Northern blot hybridized with COLIA2 and ELN probes. COLIA2 mRNA migrated at $4.8 \mathrm{~kb}$ and $E L N$ migrated at $3.5 \mathrm{~kb}$. To allow detection of $\mathrm{mRNA}_{\mathrm{E}}, \mathrm{K}$. T. cells were pretreated with $10 \mathrm{ng} / \mathrm{ml}$ TGF- $\beta 2$ for $2 \mathrm{~d}$. TGF- $\beta$ was added (control) or maintained $(K T)$ in half the cultures at the same time that cultures were treated with $60 \mathrm{mM}$ DRB at $0 \mathrm{~h}$ to block transcription, and RNA was isolated from sister cultures at the indicated times. $B$ shows densitometric analysis of autoradiographic images of $m R N A_{E}$ in panel $A$. Data were normalized to the intensity of the $28 \mathrm{~s}$ ribosomal band (not shown) and presented as arbitrary units. Estimated $t_{1 / 2}$ of mRNA $_{E}$ in control and $\mathrm{K}$. T. strains without or with TGF- $\beta$ were, respectively, 7.4 vs $9.8 \mathrm{~h}$ and 0.14 vs $2.54 \mathrm{~h}$.

cell strains. Studies by others (11) have supported these findings by examining $\mathrm{mRNA}_{\mathrm{E}}$ levels in cultured fibroblast strains. Although many $C L$ strains can show reduced elastin production in cell culture, the precise biochemical defects in this disease are still unknown. Two strains with elastin production defects were examined initially in this study, one having very reduced and the other undetectable levels of elastin production. These defects could have arisen from structural rearrangements of the elastin molecule due to mutations, or they could represent faulty regulation of the elastin gene. Although the precise biochemical defect in this syndrome is still unknown, disregulation of elastin production appears to be one of the important primary defects that bring about the CL phenotype.

In light of observations on increased elastin production stimulated by TGF- $\beta$ both in vitro and in vivo $(23,24,41)$, we began experiments to determine whether this cytokine could augment elastin production in cells expressing an elastin deficiency. The results show that TGF- $\beta$ is able to stimulate elastin production in the two CL cell strains we tested to levels approaching that of control skin fibroblast strains. Thus, given the appropriate stimulus, these CL cell strains are clearly capable of producing and secreting elastin precursors which are immunoreactive in a competitive protein binding assay and whose elastin transcripts are indistinguishable, at least in size, from 


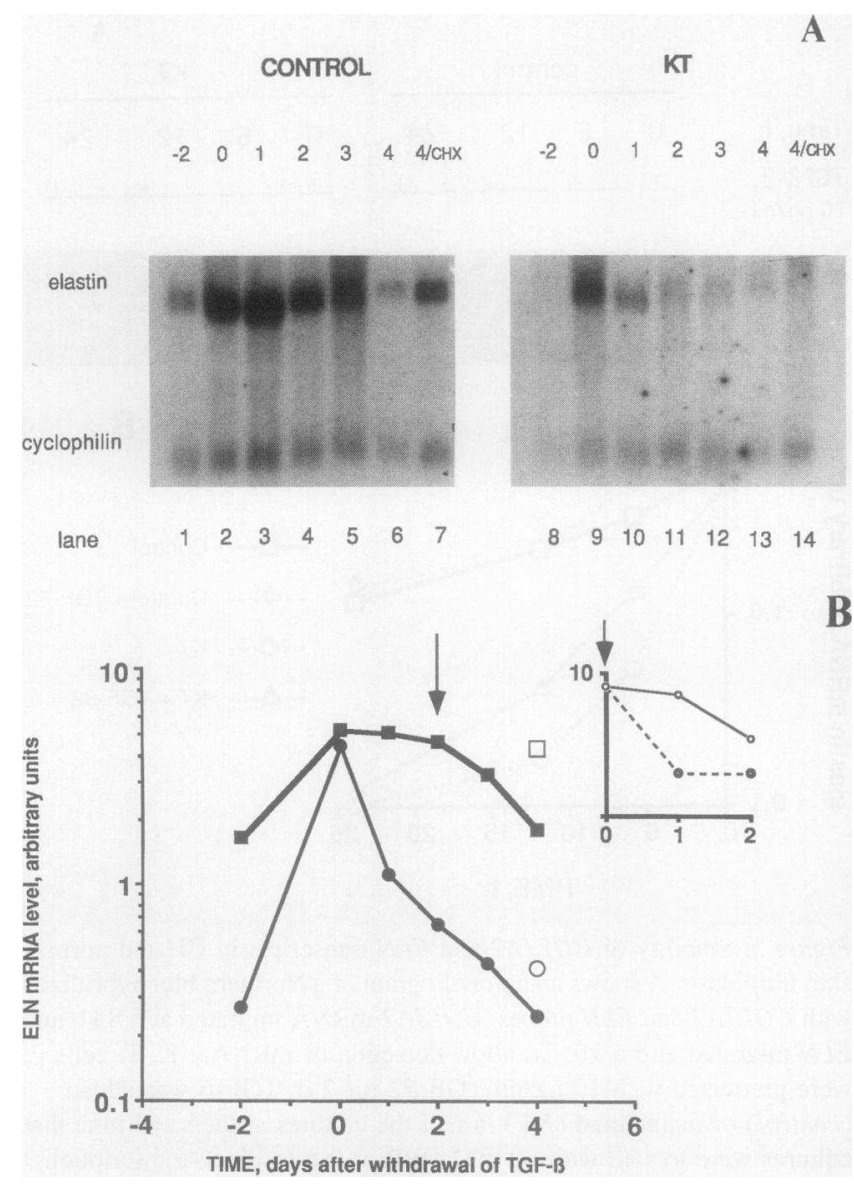

Figure 6. Elastin mRNA decay after withdrawal of TGF- $\beta$. $A$ shows an autoradiogram of control and K. T. RNAs. Confluent fibroblast cultures were treated with $10 \mathrm{ng} / \mathrm{ml}$ of TGF- $\beta 2$ in DME containing $10 \%$ FBS for $2 \mathrm{~d}$. Cells were washed $5 \times$ with PBS and refed with fresh DME, $10 \%$ FBS. $2 \mathrm{~d}$ after withdrawal of TGF- $\beta, 20 \mu \mathrm{g} / \mathrm{ml} \mathrm{CHX}$ was added to one set of cultures and exposed to the drug for $2 \mathrm{~d}$. Total RNA was isolated at $-2,0,1,2,3$, and $4 \mathrm{~d}$, after TGF- $\beta 2$ withdrawal, separated on a $1 \%$ agarose gel, and hybridized to the 1.65 -kb human elastin 3 'UTR and 0.6-kb mouse cyclophilin cDNA probes. Numbers above figure indicate days before or after withdrawal of TGF- $\beta 2$. Recovery of RNA was poor in the K. T. $-2 \mathrm{~d}$ sample, but recovery differences were corrected by normalization to cyclophilin, a TGF- $\beta$ insensitive, constitutive probe. $B$ shows densitometric analysis of autoradiograms. mRNA bands from the autoradiogram were scanned with a densitometer and the $\mathrm{mRNA}_{\mathrm{E}}$ values were expressed relative to that of cyclophilin. Closed squares, normal (GM4390); closed circles, CL (K. T.); open square, GM4390 cells treated from days 2-4 with CHX; open circle, K. T. cells treated from days 2-4 with $\mathrm{CHX}$. Arrow indicates time of $\mathrm{CHX}$ administration. Inset shows effects of TGF- $\beta$ withdrawal on mRNA levels of K. T. fibroblasts with (open circles) or without (closed circles) CHX treatment at day 0 (arrow). The estimated half-decay times for control cultures was $3.33 \mathrm{~d}$ and $0.50 \mathrm{~d}$ for $\mathrm{K}$. T. cultures. Comparison of slopes after linear regression showed a highly significant difference in decay rate $(6.6$-fold; $P<0.01)$.

normal $\mathrm{mRNA}_{\mathrm{E}}$. The ability to recover normal elastin production rates could potentially allow an investigation of structural defects present in secreted elastin that might contribute to the reduced rates of synthesis, secretion, and accumulation observed in these patients under normal culture conditions. However, the fact that these production levels can be "normalized" by cytokine treatment suggests that the defect may lie in the path- ways involved in regulation of elastin synthesis. The results also suggest that therapeutic intervention may be possible.

TGF- $\beta 1$ and TGF- $\beta 2$ are members of a pleiotropic cytokine subfamily that is known to augment extracellular matrix accumulation through multiple mechanisms, including increased matrix gene transcription, matrix transcript stability, and reduced transcription of matrix-degrading enzyme genes (42). Previous studies established that TGF- $\beta 1$ increases elastin production in fibroblasts and smooth muscle cells (23) predominantly via stabilization of mRNA $_{\mathrm{E}}$ (reference 25 , and Zoia, O., and J. M. Davidson, unpublished observations), although promoter-reporter constructs have exhibited transcriptional responses (4345 ). In the absence of TGF- $\beta$, CL cell strains K. T. and K. L. produced little or no detectable $\mathrm{mRNA}_{\mathrm{E}}$ or elastin protein. By stimulating the accumulation of $\mathrm{mRNA}_{\mathrm{E}}$ to near-normal levels with TGF- $\beta$, it was possible to observe that CL mRNA $A_{E}$ decay was markedly stabilized in strain $\mathrm{K}$. T. by the continued presence of TGF- $\beta$. Further in vitro assays may allow us to determine whether mRNA instability is due to inefficient translation initiation, reduced elongation rates, an intrinsic structural alteration in the CL ELN gene transcripts, or increased ribonuclease activity. The effects of TGF- $\beta$ in this system emphasize the importance of posttranscriptional regulation of elastin gene expression $(25,46)$.

Findings in smooth muscle cells and normal skin fibroblasts have suggested that bFGF is a potent antagonist of TGF- $\beta$ in stimulation of elastin and collagen synthesis $(23,47)$. Reduced elastin in CL could be due to increased activation of FGFmediated signal pathways. bFGF and TGF- $\beta$ have been shown to interact under a number of circumstances $(23,48-50)$. These cytokines have many opposing actions, including the mitogenic and protease-inducing capacity of bFGF as contrasted with the growth inhibitory and matrix-stimulating properties of TGF- $\beta$. Both CL strains were much more sensitive to bFGF antagonism. In situ hybridization graphically demonstrates the antagonism of TGF- $\beta$-driven accumulation of $\mathrm{mRNA}_{E}$ by bFGF; bFGF antagonism acts by affecting steady-state levels of mRNA $A_{E}$. It is conceivable that one of the signal pathways used by bFGF may be constitutively activated in CL cell strains; however, given the observation that collagen type I production is normal in CL strains, yet bFGF reduces collagen I expression levels (23), the present data suggest that the defect in CL would have to be in a part of the signal pathway distal from common regulation of collagen and elastin.

The comparison of the nuclear run-on transcription and mRNA half-life assays strongly supports the existence of a posttranscriptional regulatory defect in elastin production in $\mathrm{K}$. T. cells. The observed transcription rate in $\mathrm{K}$. $\mathrm{T}$. cells was near normal and did not account for reduced transcript abundance. Despite marked increases in transcript abundance after TGF- $\beta$ treatment, the TE transcription rate was apparently unaffected. Transcription rates in another CL strain with normal mRNA $_{E}$ levels (9) were found comparable with that of control cells (data not shown). Differences in type I collagen and fibronectin transcription rate were found when TGF- $\beta 2$ was added to cultures. As demonstrated by mRNA half-life assays, elastin mRNA was remarkably unstable in CL. The rapid decay of newly synthesized mRNA appeared to account for the almost undetectable amount of elastin and $\mathrm{mRNA}_{\mathrm{E}}$ levels in these $\mathrm{CL}$ cells. There were parallel changes in protein production, mRNA $_{E}$ levels, and mRNA $A_{E}$ stability after TGF- $\beta$ treatment. Collagen mRNA stability, by comparison, was the same as in 
control cells. We concluded that elastin production, under the present experimental conditions, is rate limited by transcript stability rather than transcription.

These findings suggest that the defect in CL, at least in $K$. T., involves subtle changes in the structure of $\mathrm{mRNA}_{E}$ rather than truncation of one ELN allele, as appears to be the case in supravalvular aortic stenosis (16). Alternatively, CL cells may lack factors that normally protect $\mathrm{mRNA}_{\mathrm{E}}$ from degradation, or they may overexpress $m R N A_{E}$ degrading activities. Isolation and detailed characterization of regions involved in posttranscriptional processing of mRNA are being undertaken to determine whether defects in ELN transcripts can be identified by either direct structural or functional assays.

Degradation of $\mathrm{mRNA}_{\mathrm{E}}$ in $\mathrm{K}$. T. cells is markedly reduced by TGF- $\beta$, reinforcing the concept that normal and abnormal regulation of elastin production is frequently controlled posttranscriptionally (46). Since continued protein synthesis appears to be required to degrade $\mathrm{mRNA}_{\mathrm{E}}$ after TGF- $\beta$ withdrawal, it appears that either the mRNA degrading factors themselves are labile proteins or that mRNA degradation is a cotranslational process. Although $\mathrm{CL}$ is a rare syndrome, in vitro correction of an elastin synthetic defect could point to the rational application of molecules like TGF- $\beta$ as therapeutic agents in this and other regulatory mutations of connective tissue molecules.

\section{Acknowledgments}

We thank Dr. Peter Byers for kindly providing the CL fibroblast strains and Dr. Gregory Sephel for the mouse collagen probe. The late Dr. Martha Mason was responsible for the isolation of the elastin genomic clone used to prepare the EUTR-1 probe, which was then subcloned by Dr. Rita Kennedy.

This work has been supported by National Institutes of Health grants GM37387 and AG06528 and the Department of Veterans Affairs.

\section{References}

1. Uitto, J., M. J. Fazio, and A. M. Christiano. 1993. Cutis laxa and premature aging syndromes. In Connective Tissue and Its Heritable Disorders: Molecular, Genetic, and Medical Aspects. P. M. Royce and B. Steinmann, editors. WileyLiss, New York. 409-423.

2. Beighton, P. 1970. The dominant and recessive forms of cutis laxa. J. Med. Genet. 9:216-221.

3. Mehregan, A. H., S. C. Lee, and H. Nabai. 1978. Cutis laxa (generalized elastolysis): a report of four cases with autopsy findings. J. Cutaneous Pathol. 5:116-126.

4. Marchase, P., K. Holbrook, and S. R. Pinnell. 1980. A familial cutis laxa syndrome with ultrastructural abnormalities of collagen and elastin. J. Invest. Dermatol. 75:399-403.

5. Reed, W. B., R. E. Horowitz, and P. Beighton. 1971. Acquired cutis laxa. Arch. Dermatol. 103:661-669.

6. Lewis, P. G., A. F. Hood, N. K. Barnett, and K. A. Holbrook. 1990 Postinflammatory elastolysis and cutis laxa. A case report. J. Am. Acad. Dermatol. 22:40-48.

7. Braverman, I. M., and E. Fonferko. 1982. Studies in cutaneous aging. I. The elastic fiber network. J. Invest. Dermatol. 78:434-448.

8. Holbrook, K. A., and P. H. Byers. 1982. Structural abnormalities in the dermal collagen and elastic matrix from the skin of patients with inherited connective tissue disorders. J. Invest. Dermatol. 79(Suppl. I):7-16.

9. Sephel, G. C., P. H. Byers, K. A. Holbrook, and J. M. Davidson. 1989. Heterogeneity of elastin expression in cutis laxa fibroblast strains. J. Invest. Dermatol. 93:147-153.

10. Uitto, J., and A. Shamban. 1987. Heritable skin diseases with molecular defects in collagen or elastin. Dermatologic Clinics. 5:63-84.

11. Olsen, D. R., M. J. Fazio, A. T. Shamban, J. Rosenbloom, and J. Uitto. 1988. Cutis laxa: reduced elastin gene expression in skin fibroblast cultures as determined by hybridizations with a homologous cDNA and an exon 1-specific oligonucleotide. J. Biol. Chem. 263:6465-6467.
12. Davidson, J. M., and M. G. Giro. 1986. Control of elastin synthesis: molecular and cellular aspects. R. P. Mecham, editor. Academic Press, Inc., New York. 177-216.

13. Uitto, J., M. J. Fazio, M. Bashir, and J. Rosenbloom. 1991. Elastic fibers of the connective tissue. In Physiology, Biochemistry, and Molecular Biology of the Skin. L. A. Goldsmith, editor. Oxford University Press, New York. 533-557.

14. Rosenbloom, J. 1984. Elastin: relation of protein and gene structure to disease. Lab. Invest. 51:605-623.

15. Neldner, K. 1993. Pseudoxanthoma elasticum. In Connective Tissue and Its Heritable Disorders: Molecular,Genetic, and Medical Aspects. P. M. Royce and B. Steinmann, editors. Wiley-Liss, New York. 425-436.

16. Curren, M. E., D. L. Atkinson, A. K. Ewart, C. A. Morris, M. F. Leppart, and M. T. Keating. 1993. The elastin gene is disrupted by a translocation associated with supravalvular aortic stenosis. Cell. 73:159-168.

17. Ewart, A. K., C. A. Morris, D. Atkinson, W. Jin, K. Sternes, P. Spallone, A. D. Stock, M. Leppert, and M. T. Keating. 1993. Hemizygosity at the elastin locus in a developmental disorder, Williams syndrome. Nature Genetics. 5: $11-16$.

18. Pyeritz, R. E. 1993. The Marfan syndrome. In Connective Tissue and Its Heritable Disorders: Molecular,Genetic, and Medical Aspects. P. M. Royce and B. Steinmann, editors. Wiley-Liss, New York. 436-468.

19. Giro, M. G., M. Duvic, L. T. Smith, R. Kennedy, R. Rapini, F. C. Arnett, and J. M. Davidson. 1992. Buschke-Ollendorff syndrome associated with elevated elastin production by affected skin fibroblasts in culture. J. Invest. Dermatol. 99:129-137.

20. Mecham, R. P., S. L. Morris, B. D. Levy, and D. S. Wrenn. 1984. Glucocorticoids stimulate elastin production in differentiated bovine ligament fibroblasts but do not induce elastin synthesis in undifferenciated cells. J. Biol. Chem. 259:12414-12418.

21. Parks, W. C., M. E. Kolodziej, and R. A. Pierce. 1992. Phorbol estermediated downregulation of tropoelastin expression is controlled by a posttranscriptional mechanism. Biochemistry. 31:6639-6645.

22. Foster, J. A., C. B. Rich, and J. R. Florini. 1987. Insulin-like growth factor I, somatomedin c, induces the synthesis of tropoelastin in aortic tissue. Collagen Relat. Res. 7:161-169.

23. Davidson, J. M., O. Zoia, and J.-M. Liu. 1993. Modulation of transforming growth factor-beta 1 stimulated elastin and collagen production and proliferation in porcine vascular smooth muscle cells and skin fibroblasts by basic fibroblast growth factor, transforming growth factor- $\alpha$, and insulin-like growth factor-I. $J$. Cell. Physiol. 155:149-156.

24. Liu, J.-M., and J. M. Davidson. 1988. The elastogenic effect of recombinant transforming growth factor beta on porcine aortic smooth muscle cells. Biochem. Biophys. Res. Commun. 154:895-901.

25. Kahari, V.-M., D. R. Olsen, R. W. Rhudy, P. Carrillo, Y. Q. Chen, and J. Uitto. 1992. Transforming growth factor- $\beta$ up-regulates elastin expression in human skin fibroblasts: evidence for post-transcriptional modulation. Lab. Invest. 66:580-588.

26. Giro, M. G., and J. M. Davidson. 1993. Familial co-segregation of the elastin phenotype in skin fibroblasts from Hutchinson-Gilford progeria. Mech. Ageing Dev. 70:163-176.

27. Kahari, V.-M., Y. Q. Chen, M. M. Bashir, J. Rosenbloom, and J. Uitto. 1992. Tumor necrosis factor- $\alpha$ regulates human elastin gene expression: evidence for the role of AP-1 in the suppression of promoter activity. J. Biol. Chem. 267:26134-26141.

28. Angerer, L. M., M. H. Stoler, and R. C. Angerer. 1987. In situ hybridization with RNA probes: an annotated recipe. In In Situ Hybridization, Application to Neurobiology. K. L. Valentino, editor. Oxford University Press, New York. 4270.

29. Giro, M. G., A. I. Oikarinen, H. Oikarinen, G. Sephel, J. Uitto, and J. Davidson. 1985. Demonstration of elastin gene expression in human skin fibroblast cultures and reduced tropoelastin production by cells from a patient with atrophoderma. J. Clin. Invest. 75:672-678.

30. Labarca, C., and K. A. Paigen. 1980. Simple, rapid and sensitive DNA assay procedure. Anal. Biochem. 102:344-352.

31. West, D. C., A. Sattar, and S. Kumar. 1985. A simplified in situ solubilization procedure for the determination of DNA and cell number in tissue cultured mammalian cells. Anal. Biochem. 147:289-296.

32. Fazio, M. J., D. R. Olsen, H. Kuivaniemi, M.-L. Chu, J. M. Davidson, J. Rosenbloom, and J. Uitto. 1988. Isolation and characterization of human elastin cDNA and age-associated variation in elastin gene expression in cultured skin fibroblasts. Lab. Invest. 58:270-277.

33. Bernard, M. P., J. H. C. Myers, M. Chu, F. Ramirez, E. F. Eikenberry, and D. J. Prockop. 1983. Structure of cDNA for the proa 2 chain of human type I procollagen: comparison with chick cDNA for pro $\alpha 2$ (I) identifies structurally conserved features of the protein and the gene. Biochemistry. 22:1139-1145.

34. Quaglino, D., L. B. Nanney, R. Kennedy, and J. M. Davidson. 1990. Localized effects of transforming growth factor-beta on extracellular matrix gene expression during wound healing. I. Excisional wound model. Lab. Invest. 63:307-319.

35. Muthukumaran, G., B. Blumberg, and M. Kurkinen. 1989. The complete 
primary structure for the $\alpha 1$-chain of mouse collagen IV. J. Biol. Chem. 264:6310-6317.

36. Bernard, M. P., M. Kolbe, D. Weil, and M. L. Chu. 1985. Human cellular fibronectin: comparison of the carboxyl-terminal portion with rat identifies primary structural domains separated by hypervariable regions. Biochemistry. 24:2698-2704.

37. Pennica, D., J. S. Hayflick, T. S. Bringman, M. A. Palladino, and D. V. Goeddel. 1985. Cloning and expression in Escherichia coli of the cDNA for murine tumor necrosis factor. Proc. Natl. Acad. Sci. USA. 82:6060-6064.

38. Angel, P., I. Baumann, B. Stein, H. Delius, H. J. Rahmsdorf, and P. Herrich. 1987. 12-O-tetradecanoyl-phorbol-13-acetate induction of the human collagenase gene is mediated by an inducible enhancer element located in the $5^{\prime}$ flanking region. Mol. Cell. Biol. 7:2256-2266.

39. Chomczynski, P., and N. Sacchi. 1987. Total RNA isolation from cell cultures. Anal. Biochem. 162:156-159.

40. Danielson, P. E., S. Forss-Petter, M. A. Brow, L. Calavetta, J. Douglass, R. J. Milner, and J. G. Sutcliffe. 1988. p1B15: a cDNA clone of the rat mRNA encoding cyclophilin. DNA (NY). 7:261-267.

41. Quaglino, D. J., L. B. Nanney, J. A. Ditesheim, and J. M. Davidson. 1991. Transforming growth factor-beta stimulates wound healing and modulates extracellular matrix gene expression in pig skin: incisional wound model. $J$. Invest. Dermatol. 97:34-42.

42. Massagùe, J. E., B. M. Alberts, and J. A. Spudich. 1990. The transforming growth factor- $\beta$ family. In Annual Reviews of Cell Biology, Vol 6. G. E. Palade, B. M. Alberts, and J. A. Spudich, editors. Annual Reviews Inc., Palo Alto, CA. 597-641.
43. Katchman, S. D., S. Hsu-Wong, I. Ledo, M. Wu, and J. Uitto. 1994. Transforming growth factor- $\beta$ up-regulates human elastin promoter activity in transgenic mice. Biochem. Biophys. Res. Commun. 203:485-490.

44. Marigo, V., D. Volpin, and G. M. Bressan. 1993. Regulation of the human elastin promoter in chick embryo cells. Tissue-specific effect of TGFbeta. Biochim. Biophys. Acta. 1172:31-36.

45. Marigo, V., D. Volpin, G. Vitale, and G. M. Bressan. 1994. Identification of a TGF-beta responsive element in the human elastin promoter. Biochem. Biophys. Res. Commun. 199:1049-1056.

46. Parks, W. C., R. A. Pierce, K. A. Lee, and R. P. Mecham. 1993. Elastin. In Advances in Molecular and Cell Biology, Vol. 6. H. K. Kleinman, editor. Jai Press Inc., Greenwich, CT. 133-182.

47. Brettell, L. M., and S. E. McGowan. 1994. Basic fibroblast growth factor decreases elastin production by neonatal rat lung fibroblasts. Am. J. Respir. Cell Mol. Biol. 10:306-315.

48. Fafeur, V., B. I. Terman, J. Blum, and P. Bohlen. 1990. Basic FGF treatment of endothelial cells down-regulates the 85-kD TGF beta receptor subtype and decreases the growth inhibitory response to TGF-beta 1. Growth Factors. 3:237-245.

49. Horton, W. E. J., J. D. Higginbotham, and S. Chandrasekhar. 1989. Transforming growth factor-beta and fibroblast growth factor act synergistically to inhibit collagen II synthesis through a mechanism involving regulatory DNA sequences. J. Cell. Physiol. 141:8-15.

50. Saksela, O., D. Moscatelli, and D. B. Rifkin. 1987. The opposing effects of basic fibroblast growth factor and transforming growth factor beta on the regulation of plasminogen activator activity in capillary endothelial cells. $J$. Cell Biol. 105:957-963. 